\title{
ГЕНЕТИКА
}

УДК 579.873.1:577.181.4

\section{STUDY OF STREPTOMYCES GHANAENSIS ATCC14672 GENES SSFG_03627 AND SSFG_01411 ENCODING PUTATIVE MEMBRANE PROTEINS}

\author{
Y. Sehin, B. Ostash
}

Ivan Franko National University of Lviv

4, Hrushevskyi St., Lviv 79005, Ukraine

e-mail: b.ostash@lnu.edu.ua

\begin{abstract}
Streptomyces ghanaensis ATCC14672 produces moenomycin A, a potent phosphoglycolipid antibiotic that targets bacterial peptidoglycan glycosyltransferases (PGTs). The genetic and biochemical aspects of assembly of moenomycin molecule is well understood. Yet, it remains unknown how moenomycins are transported from the cell into an environment, and whether the active export of moenomycin might be important for resistance of producer to its own potentially toxic secondary metabolite. There is overall structural and functional similarity between moenomycin and Lipid II an essential precursor to peptidoglycan (common lipid-glycoside scaffold, both bind PGTs). We hypothesized that proteins responsible for Lipid II transport across the $S$. ghanaensis membrane, analogous to MurJ in Escherichia coli, could also be involved in moenomycin export. In this work we describe initial genetic characterization of two MurJ-like S. ghanaensis ATCC14672 genes, SSFG_03627 and SSFG_01411. We revealed that gene SSFG_03627 is essential and could be deleted from $S$. ghanaensis ATCC14672 genome only in presence (in trans) of the second SSFG 03627 gene copy. Attempts to complement murJ-deficient E. coli NR1154 strain with either SSFG 03627 or SSFG_01411 gene were unsuccessful. Manipulations of SSFG_03627 gene copy number had complex influences on moenomycin production in $S$. ghanaensis ATCC14672.
\end{abstract}

Keywords: Streptomyces, moenomycin, antibiotic resistance, Lipid II flippases

S. ghanaensis is the producer of moenomycin A $(\mathrm{MmA})$ - founding member of a small family of phosphoglycolipid antibiotics that inhibit the growth of mostly Gram-positive bacteria, including many vancomycin- and methicillin-resistant strains. The structure of MmA features elements rarely found in the secondary metabolites of bacteria and it is the only known natural antibiotic that inhibits the transglycosylation step of bacterial cell wall synthesis through binding to the peptidoglycan transglycosylases (PGTs) [8]. This makes MmA an interesting target for drug development.

Genetic control of moenomycin biosynthesis is well studied, it is quite complex, with 17 genes being involved [7, 8]. These genes (moe) form two clusters located distantly to each other. There are no regulatory or resistance genes within either of the moe clusters, so there is a broad interest of studying other mechanisms involved in moenomycin biogenesis. One of possible research targets is to study how this molecule gets through the $S$. ghanaensis membrane, and what moenomycin resistance mechanisms are. It has been shown that moenomycin inhibits PGTs, the enzymes involved in the essential penultimate step of bacterial cell wall biosynthesis through binding in the active site cleft of PGTs. In this mechanism MmA and Lipid II, an essential precursor of peptidoglycan, compete for binding to PGT [3]. If so, we suggest that enzymes involved in Lipid II translocation across $S$. ghananesis membrane might also be involved in MmA export from cells, and contribute to $S$. ghanaensis resistance to MmA. Only recently genes and

(C) Сегін Ю., Осташ Б., 2017 
enzymes for Lipid II translocation have been discovered in model organisms E. coli and Bacillus subtilis [9]. However, nothing is known about Lipid II translocation in actinomycetes and $S$. ghanaensis as well. Therefore, in our work we pursued several goals. First, we identified, in silico, homologs of E. coli Lipid II flippase in S. ghanaensis. Second, we constructed plasmids for overexpression of the identified genes in Streptomyces, and studied the effects of increased gene dosage on moenomycin production, colony morphology and overall antibiotic resistance. Third, we attempted to knock out the gene for one of the identified MurJ homolog. Fourth, we explored whether $S$. ghanaensis ATCC14672 murJ homologs are able to complement conditionally deficient $m u r J$ strain of E. coli NR1154. As a result of these experiments, we show that the studied genes influence moenomycin production but not antibiotic resistance, although their exact biological roles in S. ghanaensis remain poorly understood.

\section{Materials and Methods}

Strains used and constructed in this work are listed in Table 1. Solid oatmeal (40g/1 oat flour, 20g/l agar) and soy-mannitol media [5] were used to grow Streptomyces and plate matings. $B$. cereus and $E$. coli strains were grown in liquid or agar LB medium supplemented with appropriate antibiotic (if needed) at either 30 or $37^{\circ} \mathrm{C}$, respectively. For visual and microscopic lawn examination, strains were grown on oatmeal, soy-flour and TSB media. Vectors pKC1132 [5], pHYG, pGCymRP21, pTES, pUWLCre [11] were used for genetic engineering experiments. Genomic DNA from Streptomyces and plasmid DNA from E. coli were isolated using standard protocols [5]. Restriction enzymes and molecular biology reagents were used according to recommendation of suppliers (NEB, MBI Fermentas). Genome sequence of S. ghanaensis ATCC14672 was accessed through NCBI website.

Several plasmids were constructed in course of the work. 5-kb segment of $S$. ghanaensis ATCC14672 genome, centered on gene SSFG_03627, was amplified from S. ghanaensis ATCC14672 chromosome with primers mviNgh-largeXbaIup (AAATCTAGACATGACCAAGGCCTCCAC) and mviNgh-largeEcoRIrp (AAA GAATTCCTGCATCCGGTTCCGTTCC). Sites for restriction endonucleases (RE) are underlined in primer sequences. This segment was treated with RE XbaI and EcoRI and cloned into respective sites of pKC1132 to give pOOB100a. Gene SSFG_03627 within pOO100a was replaced with hygromycin resistance cassette from pHYG using recombineering (primers mviNgh-red-hyg-up: GCCATGCCGCGGGCAACTCGGGCCACCCCGAGTCGGATCCCCGTA- GAGATTGGCGATCCC and mviNgh-red-hyg-rp: TCAGCGTCCCAGGCGTCCGCGGACCATGCCGA- CCAGAGACAGGCGCCGGGGGCGGTGTC). The final construct for SSFG_03627 knockout was labeled as pOOB101c. Gene SSFG_03627 was amplified with primers mviNgh-XbaIup (AAATCTAGACCGTTGAGGATGTCGTGG) and mviNgh-EcoRIrp (AAAGAATTCAGCGTCCCAGGCGTCC) and cloned into XbaI-EcoRI-digested vector pTES to give expression plasmid pOOB99a. For inducible expression of SSFG_01411 2.5-kb segment of S. ghanaensis ATCC14672, genome, contained the SSFG_01411 gene, was amplified with primers ssfg_06665_up1 (AAAGATATCTAGAGTCCACC̄GCAAGATCCTCGC) and ssfg_06665_rp (AAAGGATCCGA ATTCACCGCACCCCCGGCAGGC). This segment was treated with XbaI+EcoRI and cloned into SpeI+EcoRI sites of pGCymRp21, under control of inducible P21-cmt promoter, to give pJS2. Also SSFG_03627, amplified with primers mviNgh-XbaIup (AAATCTAGACCGTTGAGGATGTCGTGG) and mviNgh-EcoRIrp (AAAGAATTCAGCGTCCCAGGCGTCC), was treated with XbaI+EcoRI and cloned into SpeI+EcoRI sites of pGCymRp21 to give pJS1.

Moenomycin was extracted from $S$. ghanaensis strains after five days of cultivation in liquid TSB medium and analyzed as described in [6]. Antibiotic resistance was analysed with disc 
diffusion method. For scanning electron microscopy (SEM), small pieces of 7-day-old sporulating lawn were cut off the oatmeal agar plate samples, vacuum-dried and directly analyzed on a Jeol JSM-T220A scanning microscope.

Table 1

Bacterial strains used in this work

\begin{tabular}{|c|c|c|}
\hline Strain & Relevant characteristics & $\begin{array}{r}\text { Source / } \\
\text { Reference }\end{array}$ \\
\hline E. coli $\mathrm{DH} 10 \mathrm{~B}$ & $\begin{array}{l}\text { Routine cloning host; } \mathrm{F}^{-} \text {mcr } \mathrm{A} \Delta(\text { mrr-hsd } \mathrm{RMS}-m c r \mathrm{BC}) \\
\varphi 80 \text { lacZ } \Delta \mathrm{M} 15 \Delta \text { lacX74 recA1 end } \mathrm{A} 1 \text { araD139 } \Delta(\text { ara, leu }) 7697 \\
\text { gal } \mathrm{U} \text { gal } \mathrm{K} \lambda^{-} \text {rpsL } \text { nup } \mathrm{G} \text {. }\end{array}$ & Invitrogen \\
\hline E. coli ET12567 pUZ8002 & 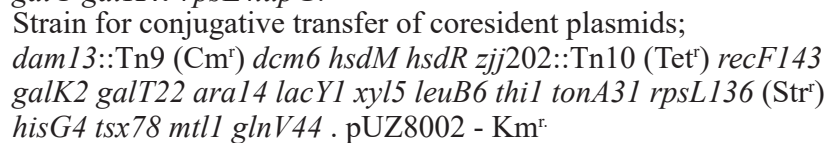 & [5] \\
\hline E. coli BW25113 pIJ790 & $\begin{array}{l}\text { F- , DE }(\text { araD-araB }) 567 \text {, lacZ4787(del)::rrnB-3, LAM- , rph-1, } \\
\text { DE(rhaD-rhaB)568, hsdR514. Contains the } \lambda \text { RED recombination } \\
\text { plasmid pIJ790. }\end{array}$ & [4] \\
\hline E. coli NR1154 & $\begin{array}{l}\text { MurJ-depletion strain; MC4100 ara }+\Delta l y s A:: \text { kan murJ } \\
\Omega\left(-14:: \text { bla araC } \mathrm{P}_{\mathrm{BAD}}\right) \text {. }\end{array}$ & [9] \\
\hline E.coli NR1154-99a & NR1154 derivative. Carries SSFG_03627 gene (pOOB99a). & This work \\
\hline E.coli NR1154 JS2 & $\begin{array}{l}\text { NR1154 derivative. Carries the } S \overline{S F} G 01411 \text { gene under control } \\
\text { of cumate-inducible promoter (pJS2 plasmid). }\end{array}$ & This work \\
\hline $\begin{array}{l}\text { Bacillus cereus } \\
\text { ATCC19637 }\end{array}$ & Moenomycin-sensitive test culture. & ATCC \\
\hline S. ghanaensis ATCC14672 & Wild type moenomycin producer. & ATCC \\
\hline S. ghanaensis YS1 & $\begin{array}{l}\text { ATCC14672 derivative. Carries the second copy of SSFG_03627 } \\
\text { gene integrated into } a t t B^{\varphi C 31} . \mathrm{Am}^{\mathrm{r}}\end{array}$ & This work \\
\hline S. ghanaensis YS2 & $\begin{array}{l}\text { YS1 derivative. pOOB99a vector sequences were excised from } \\
\text { YS1 genome with pUWLCre plasmid. Am }\end{array}$ & This work \\
\hline S.ghanaensis YS3 & $\begin{array}{l}\text { YS2 derivative. The native copy of } S S F G \_3627 \text { of YS2 genome } \\
\text { was knocked out with plasmid pOOB101c. } \mathrm{Hy}^{\mathrm{r}} \mathrm{Am}^{\mathrm{s}}\end{array}$ & This work \\
\hline S. ghanaensis JS1 & $\begin{array}{l}\text { ATCC } 14672 \text { derivative. Carries the extra copy of } S S F G \_03627 \\
\text { gene under cumate-inducible promoter (pJS1). }\end{array}$ & This work \\
\hline S. ghanaensis JS2 & $\begin{array}{l}\text { ATCC } 14672 \text { derivative. Carries extra copy of } S S F G \_01411 \text { gene } \\
\text { under cumate-inducible promoter (pJS2 plasmid). }\end{array}$ & This work \\
\hline S. albus SAM2 & Derived from $S$. albus $\mathrm{J} 1074$ by deletion of $\varphi \mathrm{C} 31$ pseB4. & [1]. \\
\hline S. albus JS1 & $\begin{array}{l}\text { SAM2 derivative. Carries the extra copy of } S S F G \_03627 \text { gene } \\
\text { under cumate-inducible promoter (pJS1 plasmid). }\end{array}$ & This work \\
\hline S. albus JS2 & $\begin{array}{l}\text { SAM2 derivative. Carries the extra copy of } S S F G \_01411 \text { gene } \\
\text { under cumate-inducible promoter (pJS2 plasmid). }\end{array}$ & This work \\
\hline
\end{tabular}

Genome sequences were accessed through NCBI. Orthologs prediction was carried out via reciprocal BLASTP analyses. Phylogenetic analysis was carried out using maximum-likelihood algorithm at www.phylogeny.fr; default parameters of phylogenetic reconstruction have been applied. Transmembrane domain prediction program TMHMM (http://www.cbs.dtu.dk/services/ TMHMM/ ) was used to analyze putative Lipid II flippases.

\section{Results and Discussion}

In silico search for MurJ homologs encoded within S. ghanaensis ATCC14672 genome. Using aminoacid sequence of E. coli MurJ, a putative flippase of Lipid II [9], we employed BLASTP to look for orthologs within S. ghanaensis ATCC14672 genome. Our initial search (in 2010) was based on analysis of partially sequenced S. ghanaensis ATCC14672 genome, and it returned protein SSFG_03627 (767 amino acids; $44 \%$ similarity over 457-aa segment) as the reciprocal best BLASTP hit (RBH). According to program TMHMM, SSFG_03627 protein featured 14 transmembrane domains. This was consistent with a hypothesis about membrane 
location of presumed Lipid II flippase. Recently we updated our ortholog search using more extensively sequenced $S$. ghanaensis ATCC14672 genome. With BLASTP program we searched RBH for SSFG_03627 in genomes of Mycobacterium tuberculosis, B. subtilis and E. coli K12 genomes. None of the hits was reciprocal this time. However, we identified another MurJ-like protein-SSFG_01411, that was RBH to all putative Lipid II flippases from the studied genomes, except for MurJ (Fig. 1). TMHMM program confirmed that SSFG_01411 had 14 possible transmembrane domains in its structure (data not shown).

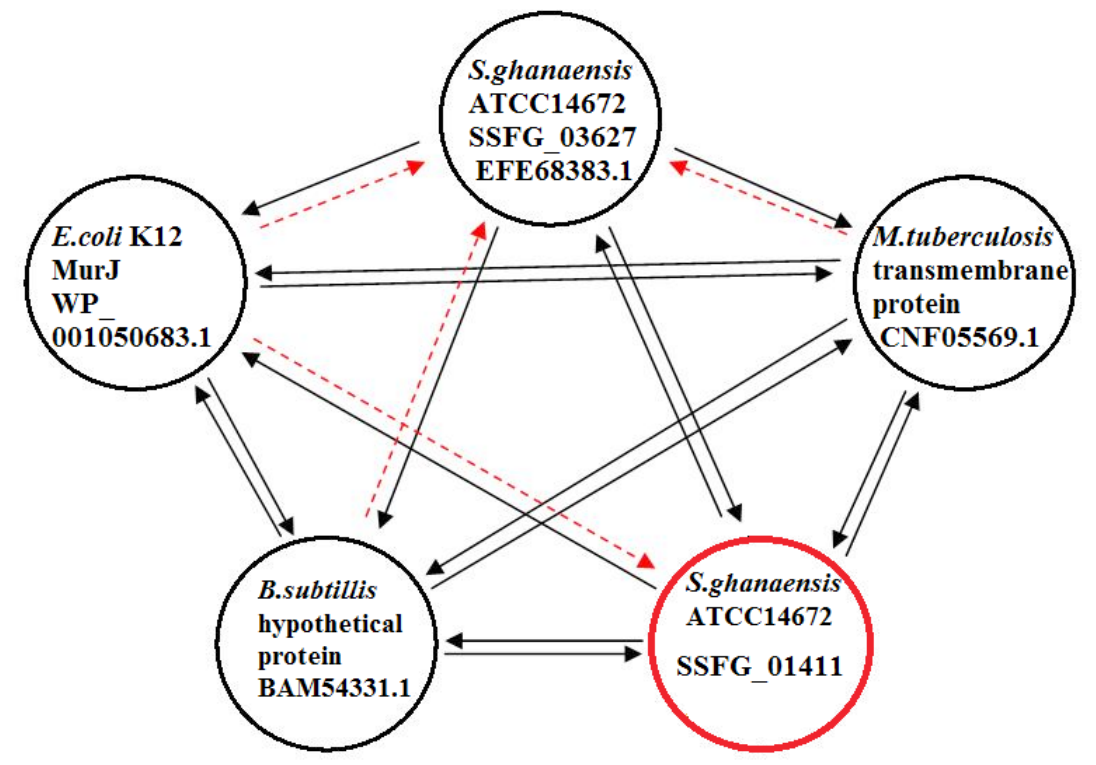

Fig. 1. Orthologous relationships (based on RBH strategy) within the group of putative Lipid II flippases from model strains and $S$. ghanaensis ATCC14672. Solid two-way arrows indicate RBH, dashed arrows indicate non-best hit (e.g., MurJ is RBH for SSFG_01411, but the latter is not RBH for MurJ). SSFG_01411 and SSFG_03627 are paralogues. In all cases $E$ value in pairwise alignments was below $3^{-10}$, implying that our findings were statistically significant

Studies of SSFG_03627 and SSFG_01411 in S. ghanaensis ATCC14762. Plasmid pOOB101c for $S S F G \_03627$ knockout (see Methods) was transferred into S. ghanaensis ATCC14672 and hygromycin-resistant $\left(\mathrm{Hy}^{\mathrm{r}}\right)$, apramycin-sensitive $\left(\mathrm{Am}^{\mathrm{s}}\right)$ clones (an indicative of SSFG_03627 replacement with $\mathrm{Hy}^{\mathrm{r}}$ cassette) were looked for. In spite of much effort, we failed to isolate viable $\mathrm{Hy}^{\mathrm{r}} \mathrm{Am}^{\mathrm{s}}$ clones; all of them grew marginally and died after one passage. These facts pointed to essentiality of $S S F G \_03627$. However, disruption of an essential gene should be possible if two copies of the latter are present in the genome. So we set out to delete native copy of SSFG_03627 in S. ghanaensis ATCC14762 genome in presence of the second SSFG_03627, located in trans. The construction of $S$. ghanaensis ATCC14762 carrying two copies of $S S F G \_03627$ was therefore carried out as follows. First, second copy of SSFG_03627 was integrated into attB $B^{\varphi(31}$ of $S$. ghanaensis ATCC14672 genome using plasmid pOOB99 $\bar{a}$. The generated strain was referred to as $S$. ghanaensis YS1. Second, pOOB99a vector sequences were excised from $S$. ghanaensis YS1 using plasmid pUWLCre to give $S$. ghanaensis YS2 (Ams). Third, native copy of SSFG_03627 was knocked out of S. ghanaensis YS2 genome with plasmid pOOB101c. Hy ${ }^{\mathrm{r}} \mathrm{Am}^{\mathrm{s}}$ clones were readily isolated, and one of them, marked as $S$. ghanaensis YS3, was verified by diagnostic PCR to carry the expected SSFG_03627 knockout (data not shown). 
Our results point that gene $S S F G \_03627$ is essential, because it could be facilely deleted from S. ghanaensis ATCC14672 genome in presence of extra copy of SSFG_03627.

Also, plasmid pJS1 was conjugally transferred into $S$. ghanaensis ATCC14672 strain. We thus generated $S$. ghanaensis JS1 strain, which carried the extra copy of SSFG_03627 gene under cumate-inducible promoter [6]. In the same way, we generated $S$. ghanaensis JS 2 strain with extra $S S F G$ _01411 copy under cumate-inducible promoter. Both plasmids were also transferred into $S$. albus SAM2.

The next purpose of our work was to investigate the phenotype of above mentioned strains. We checked their resistance to common antibiotics and revealed no differences in comparison to initial strains. No significant morphological changes were also detected. Because of both structural and chemical similarities of Lipid II and MmA, we suggested that the latter could be transported out of the cell by MurJ homologues in S. ghanaensis. We analysed the level of MmA accumulation separately in mycelium and supernatant of $S$. ghanaensis fermentation medium with the help of biochromatography. These results are summarized in Fig. 2. In S. ghanaensis YS3 strain (deletion of native $S S F G \_03627$ gene), MmA production was almost completely blocked. In the wild type background, presence of SSFG_03627, either under ermEp (pOOB99a, lanes 2M, 2S) or P21-cmt (lanes 4M, 4S) led to qualitative and quantitative changes in moenomycin production profile. Particularly, SSFG_03627 expression from plasmids caused S. ghanaensis to accumulate in mycelium as-yet-unidentified antibacterials, while accumulation of $\mathrm{MmA}$ and second most abundant phosphoglycolipid, nosokomycin B [7] was not observed. In the same time, MmA was also absent in the supernatant from $S$. ghanaensis YS1 and $S$. ghanaensis JS1 strains as compared to $S$. ghanaensis ATCC14672. Presence of extra copy of SSFG_01411 (S. ghanaensis JS2) had no effects on moenomycin production (lanes $5 \mathrm{M}, 5 \mathrm{~S}$, Fig. 2). Finally, we determined the resistance to moenomycin A in S. albus JS1 and JS2 strains; no differences were found as compared to the wild type strain.

A

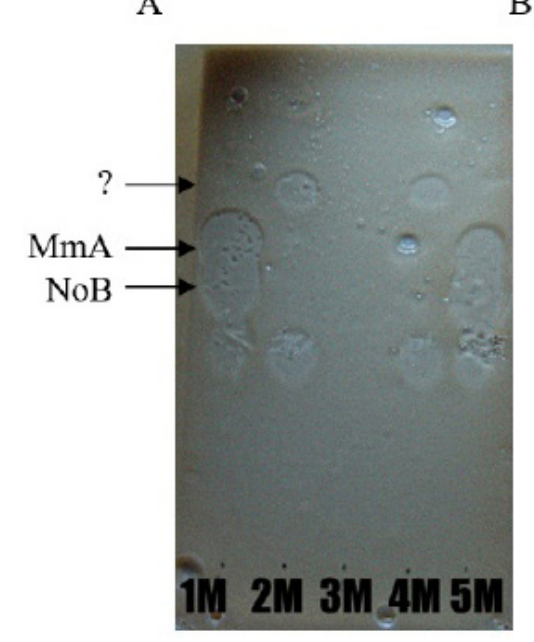

B

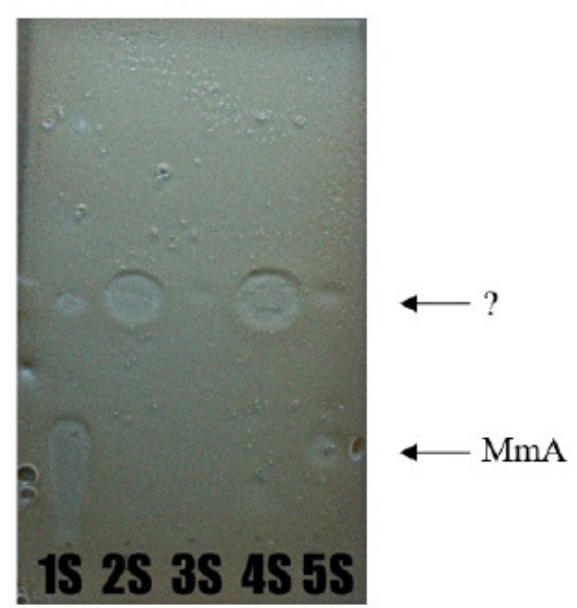

Fig. 2. Biochromatography of moenomycins extracted from mycelium (A) or supernatant (B) of following S. ghanaensis strains: ATCC14672 (lanes 1M(ycelium), 1S(upernatant)), YS1 (2M, 2S), YS3 (3M, 3S), JS1 (4M, 4S), JS2 (5M, 5S). Arrows mark bioactive spots corresponding to MmA and nosokomycin B (NoB). TLC plates shown on the photograph are representative of typical result of three independent repeats. Spot below NoB belongs to minor forms of moenomycin complex. Interrogation sign (?) marks unknown antibacterial compound, chemically unrelated to moenomycins 
Complementation of $E$. coli NR1154 with putative $S$. ghanaensis flippase genes. We attempted to complement murJ depletion strain E. coli NR1154 with either SSFG_03627 or SSFG_01411 genes. Briefly, murJ expression in E. coli NR1154 is under the control of arabinose-inducible promoter. Hence, growth (measured spectrophotometrically at $\mathrm{OD}_{600}$ ) of NR1154 depends on on the presence of arabinose in the medium. The plasmids pOOB99a (carries $\left.S S F G \_03627\right)$ and pJS2 (SSFG_01411) were introduced through electroporation into $E$. coli NR1154 to obtain $E$. coli NR1154-99a and E. coli NR1154 JS2 strains respectively. Growth of the parental strain and both $E$. coli NR1154-99a and E. coli NR1154 JS2 strains was analyzed in presence of either arabinose or rhamnose; the latter, a nonmetabolizable sugar, caused cell lysis of murJ depletion strains. We observed no complementation in case of either plasmids. Unexpectedly, we observed growth of E. coli NR1154 strain in the absence of arabinose, which might point to some unanticipated changes in $E$. coli NR1154 genome.

To summarize, we have identified, in silico, two genes, candidates for Lipid II flippase in S. ghanaensis. We provide circumstantial evidence that one of them, SSFG_03627, is essential, at least under laboratory conditions. This gene also suppresses moenomycin production when natural expression mode is altered (e.g. when native copy is deleted or additional copy of SSFG_03627 is introduced). All these data point to important role of Ssfg_03627 protein in S. ghanaensis biology, which might be related to transport of lipid-like substances across membrane. This work also underscores the importance of balanced transport processes for moenomycin production.

At the moment little can be told about function of the second gene, SSFG_01411. Its overexpression had no impact on the properties that we examined (resistance, morphology, antibiotic titers). More detailed investigation of this gene will be needed to uncover the role of this gene.

Acknowledgements. B.O. was supported by the grant BG-41Nr from Ministry of Education and Science of Ukraine.

\section{REFERENCES}

1. Bilyk B., Luzhetskyy A. Unusual site-specific DNA integration into the highly active pseudo-attB of the Streptomyces albus J1074 genome // Appl. Microbiol. Biotechnol. 2014. Vol. 98. P. 5095-104.

2. Dereeper A., Guignon $V$., Blanc G. et al. Phylogeny.fr: robust phylogenetic analysis for the non-specialist // Nucleic Acids Res. 2008. Vol. 36. P. 465-469.

3. Gampe C. M., Tsukamoto H., Wang T. S. et al. Modular synthesis of diphospholipid oligosaccharide fragments of the bacterial cell wall and their use to study the mechanism of moenomycin and other antibiotics // Tetrahedron. 2011. Vol. 67. P. 9771-9778.

4. Gust B., Chandra G., Jakimowicz D. et al. Lambda red-mediated genetic manipulation of antibiotic-producing Streptomyces // Adv. Appl. Microbiol. 2004. Vol. 5. P. 107-128.

5. Kieser T., Bibb M. J., Buttner M. J. et al. Practical Streptomyces Genetics. Norwich: John Innes Foundation. 2000. 634 p.

6. Koshla O., Lopatniuk M., Rokytskyy I. et al. Properties of Streptomyces albus J1074 mutant deficient in tRNA(Leu)(UAA) gene bldA // Arch. Microbiol. 2017. May 20. doi: 10.1007/ s00203-017-1389-7.

7. Ostash B., Campbell J., Luzhetskyy A., Walker S. MoeH5: a natural glycorandomizer from the moenomycin biosynthetic pathway // Mol. Microbiol. 2013. Vol. 90. P. 1324-38.

8. Ostash B., Doud E.H., Lin C. et al. Complete characterization of the seventeen step moenomycin biosynthetic pathway // Biochem. 2009. Vol. 48. P. 8830-8841.

9. Ruiz N. Lipid Flippases for Bacterial Peptidoglycan Biosynthesis // Lipid Insights. 2016. Vol. 13. P. 21-31. 
10. Sambrook J., Russell D. W. Molecular cloning: a laboratory manual, 3rd ed. Cold Spring Harbor, NY: Cold Spring Harbor Laboratory. 2001. 450 p.

11. Siegl T., Luzhetskyy A. Actinomycetes genome engineering approaches // Antonie Van Leeuwenhoek. 2012. Vol. 102. P. 503-16.

Стаття: надійшла до редакиії 31.05.17

доопращьована 04.07.17

прийнята до друку 06.07.17

\title{
ВИВЧЕННЯ ГЕНIВ STREPTOMYCES GHANAENSIS ATCC14672 SSFGH 03627 TA SSFGH_01411, ЩО КОДУЮТЬ ІМОВІРНІ МЕМБРАННІ БІЛКИ
}

\author{
Ю. Сегін, Б. Осташ \\ Львівський наиіональний університет імені Івана Франка \\ вул. Грушевського, 4, Львів 79005, Україна \\ e-mail: b.ostash@lnu.edu.ua
}

\begin{abstract}
Streptomyces ghanaensis АТСС14672 - продуцент моеноміцину А, фосфогліколіпідного антибіотика, що діє на бактерійні пептидогліканові глікозилтрансферази (PGTs). Генетичні та біохімічні аспекти синтезу молекули моеноміцину залишаються не цілком зрозумілими. Досі невідомо, як моеноміцини транспортуються назовні 3 клітини, і чи може активний транспорт моеноміцину бути важливим для набуття резистентності продуцента до власного потенційно токсичного вторинного метаболіта. Спостерігається загальна структурна і функціональна подібність між моеноміцином і ліпідом II - життєво важливим попередником пептидоглікану (схожа ліпідно-глікозидна основа, обидва зв'язують PGTs). Ми припускаємо, що продукти гена(ів), задіяні у транспорті ліпіду II через мембрану S. ghanaensis ATCC14672, аналогічно до MurJ Escherichia coli, можуть брати участьі в експорті моеноміцину. У цій роботі ми виконали початкову генетичну характеристику двох ідентифікованих нами $m u r J$-подібних генів S. ghanaensis ATCC14672, а саме SSFG_03627 і SSFG_01411. Ген SSFG_03627життєво важливий, і його може бути делетовано з генома $S$. ghanaensis ATCC14672 тільки за наявності додатково внесеної копії гена $S S F G$ 03627. Спроби комплементувати murJ-дефектний штам E. coli NR1154 вищезгаданими генами S. ghanaensis були невдалими. Маніпуляції з числом копій гена $S S F G \_03627$ мали складний вплив на продукцію моеноміцину в S. ghanaensis АТCC14672.

Ключові слова: стрептоміцети, моеноміцин, стійкість до антибіотиків, фліппази ліпіду II
\end{abstract}

